\title{
6 The Malta Financial Services Centre: A Study in Micro-State Dependency Management?*
}

David Fabri and Godfrey Baldacchino

\section{THE CONTEXT}

In 1988 , the newly elected Nationalist government decided to develop the Maltese Islands ${ }^{1}$ into a serious and credible offshore business location. Two years later, it formally applied for full membership of the European Union (EU). After five buoyant years which clearly indicated signs of positive growth in the offshore sector, the same government, reelected in 1992, decided to phase out offshore business and in 1994 replaced the existing law by other legislation which represented more extensive, elaborate and sophisticated ambitions. The new Labour government, elected to power in late 1996, has put on hold the island's application for EU membership. When still in opposition back in 1988, Labour Party spokespersons had raised a series of objections to the offshore legislative proposals, but the present Labour government has on a number of occasions very clearly indicated its fullest commitment to the island's aim to develop into a properly supervised and credible financial centre. It recently appointed a committee of experts which submitted a report on developing Malta's financial services industry by exploiting its location on the periphery of the EU. ${ }^{2}$ There is broad political consensus on the island that financial services should remain one of the major growth areas of the economy.

\footnotetext{
* The views expressed in this chapter are those of its authors and not necessarily those of the Malta Financial Services Centre or the University of Malta. We are grateful to Jason Abbott, Mark Hampton and David Milne for comments on an earlier draft. The usual disclaimers apply.
} 


\section{This Chapter}

Drawing on a number of officially published documents, this chapter traces the more significant steps in the island's recent attempts to locate itself as a credible and serious international financial and commercial location. It also focuses on the development of the Malta Financial Services Centre, a regulatory authority which owes its existence to the 1988 offshore legislation. Since 1994, this authority has been transformed into a more complex and composite regulatory body whose competence now spans both offshore and domestic business.

This chapter does not purport to analyse in great depth the development of Malta's offshore experience; it does however try to explain the significant features of the Malta Financial Services Centre, which in a number of respects provides an interesting model for regulatory bodies set up to supervise financial services in small island states, and of some of the problems that they face.

Such an analysis is carried out in the context of a comparative exposition on the location of small island territories within the global architecture. Their predicament as small, isolated platforms saddled with a variety of impediments to development has led to so many of these territories seeking to promote themselves as international financial services, this being one of their few competitive advantages. But, like other service sector activities addressed at tapping foreign markets, it is no panacea for the problems economic development and brings along with it its own set of pitfalls and problems.

\section{Made for Each Other?}

Offshore financial centres and small island locations may appear to have been intended for each other. Small island economies habitually involve very few significant domestic transactions, given the minuteness and relative poverty of the local market. They must therefore seek to tap foreign sources of income, markets and investment, making up for their structural weaknesses by drawing in rent surpluses from elsewhere (Kakazu, 1994). When this happens successfully, they typically operate as enclaves (Munck, 1988, pp. 48-53), proudly boasting of a relatively substantial market which behaves as a monstrous appendix, with few if any links with the domestic host. This condition might be exactly what offshore finance clients may be looking for: the opportunity for tax evasion and financial transactions in an economic context which is operating in a less intrusive and oppressive tax environment and which is 
effectively at a safe distance from the prying regulatory eyes of fiscal or revenue authorities.

That such a host happens to be also a small and insular state appears to increase its attraction to offshore finance. Given that so many offshore finance centres are small and insular is no simple coincidence. Insularity increases the potential for internal confidentiality and the endogenous control of information in a setting resembling a 'self contained universe' (Brock and Smawfield, 1988, p. 232). Meanwhile, smallness may be seen to reduce the ability of a regulatory regime to develop the expertise and executive capacity required for professional scrutiny and monitoring (Bray and Fergus, 1986, pp. 94-5). The latter in particular is a worrying possibility to small islanders and Maltese parliamentary debates afford a privileged articulation of these fears.

\section{HISTORICAL BACKDROP}

In 1988, the Maltese Parliament passed legislation in an effort to establish the island as an offshore business and finance location of repute. The law put in place the necessary framework for the setting up of trading, holding, banking and insurance offshore companies, as well as offshore trusts, and provided for a number of fiscal and other beriefits for promoters who choose to establish an offshore operation on the island. It also established a new autonomous regulatory authority assigning it full responsibility for the licensing and supervision of offshore activities carried out from Malta, and arming it with extensive powers of investigation and intervention.

The first offshore company was registered on 4 August 1989. By the end of 1996 , the number of registered offshore companies, including five offshore banks, had reached 2400 . It is now no longer possible to set up new offshore companies in Malta because registrations ceased on 31 December 1996. Offshore companties on the register on that date can continue to operate and exist as offshore companies until 23 September 2004 , or until the lapse of ten years from the date of their incorporation, whichever occurs the earlier. The reasons for this policy $U$-turn will be explored further on in this chapter.

With the promulgation of the Malta International Business Activities Act in 1988, Malta did not just venture into offshore business out of recklessness or desperation. Nor can it be considered to have been a leap into the unknown. Indeed, the island already enjoyed an 'intermediately developed economy' (Briguglio, 1988, p. 177), a substantial 
manufacturing base was in place, tourist inflows were reaching new levels, and a satisfactory standard of living had already been aclieved. Since 1965 the island had already had its own well-established company law. This law had been broadly modelled on the Englislı Companies Act of 1948, and was administered by the Office of the Registrar of Partnerships, a state department. As at August 1989 - when the first offshore company was registered - no fewer than 10872 limited liability companies were registered, no mean feat for a resource-poor micro-state of some 380000 people. By the end of May 1998, the number of onshore companies had shot up to 23025.

The Maltese island archipelago, in contrast to most other microstates, also boasted of a fairly long and reputable banking and financial tradition. Local banking and insurance initiatives were already established by the mid-nineteenth century (Whitmore, 1988). In 1969, a Central Bank had been set up as an independent public authority following the adoption of the Central Bank of Malta Act two years earlier. In 1970, the Maltese Legislature passed the island's first Banking Act which created what was, for the time, an appropriate regulatory framework for the undertaking of banking activities. This law, which was administered by the Central Bank, defined 'banking activities' and provided for the licensing and supervision of banking companies. In 1981, a comprehensive law dealing with the regulation of insurance businesses was also adopted. As far as maritime trade is concerned, the Merchant Shipping Act of 1973 offered various fiscal advantages to non-resident shipowners who register vessels under the Maltese flag. ${ }^{3}$

\section{A Late Start}

Ironically, in spite of this track record, offshore financial services were not really considered as a viable economic option for Malta until the late 1980s. The six Development Plans which covered the 1959-88 period disclose a profound lack of interest in this sector. The long, and in retrospect costly, delay in setting up this industry in Malta demands some explanation.

First of all, the Labour governments which dominated Maltese politics over the period 1971-87 were very suspicious of offshore tax havens. Being all too keen to widen and deepen state intervention and national economic sovereignty in all aspects of society, the Maltese state could hardly be expected to consider offering up the island as a base to tax-avoiding, foreign capitalists. Second, and related to the first, the Labour Party in government continued to be gripped by a paradigm of 
development whose main pillar was unreservedly manufacturing. Despite advice to invest more vigorously in a diversified services sector (Metwally, 1977), the potential of expanding service provision in the Maltese economy was neglected, to the exclusion of the obvious contribution of tourism. This stance would also affirm the Labour Party's distinct interest in cultivating an industrial working class sympathetic to its left-wing policies.

This was the backdrop in 1988 when Parliament passed the Malta International Business Activities Act (Act XXXIV of 1988, brought into force between 20 January and 30 June 1989). The purpose of the Act was to create a complete and proper legal framework for the launching of Malta as a well-regulated and reputable offshore business location. The publication of the Act had been preceded by a brief White Paper where the government explained the general direction it intended to pursue. In its first paragraph, it introduced the concept of offshore business to Malta:

The Government has now decided that Malta's unique combination of geographical location, its historical and cultural evolution, its superb climate and its excellent and efficient human resource make it ideally suited to develop into an international financial and trading centre. ${ }^{4}$

Offshore business was designed to become one of the pillars of the economy. Expanding on the objectives which the government was now seeking to pursue, and the dangers it was seeking to avoid, the White Paper proceeded to explain that a new opportunity for the creation of work and wealth had been identified:

Having what is expected to be the largest market in the world to its North, and the natural wealth and resources of the countries to its South and East, Malta is determined to establish itself as a reputable international financial and trading centre, with enterprises that will have a plysical and functional presence as distinct from brass plate identity. To stress Malta's commitment to its development as an offshore financial centre, the Government has drawn up and will be promulgating legislation, a central feature of which will be the setting up of an Authority with responsibility for developing and supervising offshore banking, insurance and trading companies.

The offshore opportunity was therefore perceived as an additional opportunity for the creation of new work, a goal which could be largely 
achieved on the strength of the legal structures already available but which until then still reflected a mainly local or domestic context. These structures already guaranteed an adequate framework for the regulation and undertaking of local commercial enterprise, and would have only required some adjustments to permit the provision of an offshore incorporation facility. The offshore legislation was, as we have already seen, not created in a vacuum, and the new offshore structures were simply placed alongside the existing legal structures. What had originally been a legislative framework which was largely insular in scope and approach now saw a new international dimension superimposed on the established systems. The White Paper adds that the experts advising government in this undertaking ${ }^{6}$ recommended that the creation of the offshore centre should represent the beginning of a longer-term objective to develop the newly created facility into a more sophisticated and ambitious project:

It should be implicit in our thinking that at a future date the distinction between offshore and onshore business should be eliminated and a free open centre established as in London, Switzerland and Luxembourg. The attainment of this long term objective would depend largely on the success achieved ...

These considerations were later reflected in the first official brochure of the regulatory authority set up in terms of the 1988 Act, the Malta International Business Authority (MIBA). Issued in 1989, this document contained a comprehensive explanation of the offshore legislation and its background. One paragraph explained that:

these laws were designed to complement and adapt existing Maltese legislation for an emerging international fillancial and trading centre by maintaining a strict initial distinction between onshore and offshore activities. This distinction shall be eliminated as soon as the right social and economic conditions prevail, Malta's longerterm ambition being to evolve into a free open financial and trading centre.

The bill on the offshore legislation, and subsequent amendments, did not enjoy an easy passage through Parliament. The debate is instructive because it identifies Malta's predicament as a small island state in relation to the potential economic benefits accruing from offshore banking, along with the dangers and threats that the activity presented. 
In the course of its second reading and committee stage, the (then Labour) Opposition repeatedly voiced concerns that the island risked becoming a haven for illicit and money-laundering activities. The government was accused 'of putting confidentiality on a pedestal and that the predominance of the confidentiality of secrecy would turn Malta into a centre of crime'. ${ }^{7}$ The excessive secrecy introduced by the legislation was accused of risking the attraction towards Malta of undesirable people whose identity would be concealed. ${ }^{8}$ Malta's initiative to embark on this adventure was also presented as a source of ridicule:

Malta is perceived as a banana republic... we have ended up as a banana republic without having any bananas... we are not being taken seriously. ${ }^{9}$

The Malta International Business Activities Act was approved by Parliament on 2 November 1988, coming into force in gradual stages during 1989. Section 2(1) of the Act defined offshore activity as referring to:

any business or other activity carried on from Malta in a foreign currency by persons and with persons not resident in Malta or with another offshore company or with an offshore trust.

Offshore business was therefore restricted to non-residents, and in a broad sense comprised activities which were to be carried on outside Malta from a base physically present in Malta. Maltese residents could not acquire or hold slıares in Maltese offshore companies. A breach of this prohibition amounted to an offence under the exchange control regulations and could lead to the cancellation of the company's registration and to its dissolution.

Brass-plate and shell or 'paper' companies were discouraged. ${ }^{10}$ Trading offshore companies had to demonstrate that they had an actual physical presence on the island, meaning that at the very least a management agreement had been entered into with a locally-based manager to assume responsibility for running the company's affairs in Malta. They also had to explain their company's commercial plans. Although offshore companies were not permitted to engage in trading activities in Malta, they were expected to carry out this activity from their place of business or management on the island. This requirement encouraged the renting of local commercial premises and the engagement of local personnel. 
In terms of Section 22(1) of the Act, offshore companies had to be private companies whose objects were 'expressly limited to offshore activities and to such other acts only as are necessary for its operations from Malta'. An offshore company could not own property in Malta other than bank accounts, furniture and equipment 'reasonably required for the purpose of its operations from Malta'. These provisions highlight the legislator's desire to construct an almost impregnable wall between offshore and onshore activity.

The Act established a strong autonomous regulatory authority - then called the Malta International Business Authority (MIBA) - with responsibility to administer the Act. This gave MIBA extensive powers to authorise, supervise and investigate the operators in this new sector. The Act clearly highlighted the pivotal role that the Authority was being expected to fulfil, expressly setting it up as the 'centre and channel' through which all state departments and other public authorities on the one hand and the offshore operators on the other were to communicate with one another with regard to matters relating to the operators and their offshore activities. This included correspondence on and applications for government permits, licences, official inspections and investigations. This mechanism allowed the Authority to be kept abreast of relevant developments concerning its licensees, to be in a position to intervene or to offer support where warranted, and to preempt and possibly resolve potential or actual bureaucratic hassles.

All offshore activity carried out from Malta had to be duly authorised, and registration fees had to be paid to the Authority. Some of these fees were rather on the high side, perhaps in an effort to discourage questionable business in search of a jurisdiction which exercises little screening and monitoring. Much of this screening was done in the first place by specially licensed agents called 'nominee companies' (see below) on the basis of guidelines on 'Acceptance of Business' issued to these nominee companies by the Authority, which upon its inception established strong (and rather inflexible) policies backed by administrative mechanisms intended to rule out disreputable or questionable applicants.

Another relevant feature of the regulatory set-up was the prohibition on offshore companies to issue bearer shares. Bearer shares are widely used in offshore tax havens particularly because they offer extensive guarantees of secrecy as well as ease and immediacy of ownership transferability. The ownership of any offshore undertaking registered under Maltese law was in all cases to be established and verified, and in the case of trading companies their particulars accompanied by 
appropriate references had to be furnished to the Authority. Much of this work was carried out by 'nominee companies': these were Malteseregistered companies largely staffed by professionally qualified practitioners.

Every offshore company, with very few exceptions, had to have a resident nominee company which acted as an authorised intermediary between the offshore companies and their shareholders on one hand and the Authority on the other. The institution of the nominee company merits attention as it represents one of the more innovative and interesting features of the offshore legislation, and it played a highly influential role in the promotion and the development of Maltese offshore business. From the regulator's point of view, the nominee company acted as the principal intermediary between the regulator and the non-resident investors. It also served as a first watchdog against undesirable promoters and against the improper or illegitimate use of offshore companies. From the non-resident shareholder's point of view, the nominee company and its associated companies were usually in a position to provide a range of professional services, in the relevant areas of law, tax and accounting. It acted as a guarantor of privacy since it appeared as nominee for the actual beneficial shareholder in all the public documents, including the memorandum and articles deposited with the Registrar of Companies and accessible to public inspection. Only the nominee company could act as a nominee for foreign shareholders; any other nominee arrangement breached the law. ${ }^{11}$

The nominee company could also act as a director for an offshore company. When it did so, it acted as a director in its own right and under its responsibility as there is no concept of nominee directorship. Seeing that a company under Maltese law need not have more than one director, the nominee company could fill that role by itself, without the non-resident shareholders having to appoint any additional persons. This meant that a higher degree of confidentiality was secured for the shareholders, while the nominee, company's interventionary role in the offshore company's affairs also increased. The latter feature brought a greater degree of comfort for the regulator in that the offshore company would less likely be used for the wrong reasons. The 1988 White Paper had this to say about the nominee companies:

Maltese companies are thus given the opportunity to earn money by providing the necessary service to offshore companies; but on the other hand they are given the duty and responsibility to help in ensuring the reputation of Malta as a respectable business centre. They are 
required to ensure, particularly when acting as nominees, that their activities with due respect to the laws of Malta, as applied to them, and not to serve as a screen for international crime. Other measures, both administrative and legislative, will be taken to protect the centre from its misuse by international criminals or their financiers, besides the duties imposed on nominee companies, and other provisions contained in the Bill. The draft law provides in-built safeguards and measures of protection against such a misuse. ${ }^{12}$

The nominee company could hold any number of shares on behalf of the non-resident shareholders. This proved useful where the offshore client was a single individual as it facilitated compliance with the then company law requirement that a company had to have at least two members.

In order to establish a nominee company, a warrant was required from the MIBA Board of Governors. Stringent application and qualification requirements were laid down in the Act, evidently to ensure that the persons who wished to undertake this activity were fit and proper, possessing adequate levels of professional qualifications, reliability and good conduct. The nominee company was envisaged by the Authority as a partner in trying to draw legitimate international business to Malta and to keep the new business as far as possible tidy and noncontroversial, in the best interest of all, practitioners and regulators alike. In this respect, Malta's offshore structure set itself apart from other more properly called offshore tax havens scattered around the globe which have broadly sought business by offering non-intrusive regulation coupled with low incorporation costs.

\section{A Radical Change}

September 1994 saw the coming into existence of the Malta Financial Services Centre. The Centre grew out of the former MIBA. Following a number of amendments to the 1988 Act, the Authority formerly limited to offshore business was developed and transformed into a more complex regulatory body with supervisory responsibility for important sections of domestic onshore business. In 1994, the government decided on a radical change of course. It decided that offshore business was to be phased out, and any new registrations were only possible up to 31:December 1996. The companies still on the offshore register will eventually have to terminate their offshore status by 23 September $2004 .^{13}$ 
The Authority was not dissolved or phased out. On the contrary, a number of legislative changes were made to its compelence, lunctions and powers. It retained its exclusive supervision over offshore companies, but its competence was now extended beyond strictly offshore business. A few months before the 1994 amendments were presented to Parliament, another brief White Paper was published to explain why the government was contemplating this radical movement away from offshore after such a short span of time. ${ }^{14}$ In a conference paper presented in 1995, the first chief executive of the Malta Financial Services Centre, Dr Andre Camilleri, explained the reforms in these terms:

Malta has recently carried out an extensive exercise in upgrading its financial services profile, from a basic but well-regulated 'offshore' location to a Centre that offers more sophisticated and broader structures and services... The decision of the Maltese Government to set up an international financial centre... stems from the conviction that financial services will enhance the economic diversification of Malta, and become one of the important areas in the local economy. At the same time, the drafters and legislators must have been guided by other considerations:

- the selected regulatory model had to fit into the existing body of Maltese law;

- though by no means aspiring towards permanence, the laws were to be compatible with Malta's existing and foreseeable international commitments, be they enshrined in bilateral treaties or in European Directives and policies;

- as stated earlier, the Centre would not offer everything to everyone. The safeguarding of reputation and prudent regulation were policy choices made at the very start of our venture into the international financial services field. ${ }^{15}$

Dr Camilleri has also stated in an interview that:

The offshore activity alone was not sustainable in the long term because it was encapsulated into a cocoon, cut off from the local economic activities and isolated from the other financial services. ${ }^{16}$

Practitioners engaged in the financial sector voiced concerns that the change was being undertaken too quickly. Some felt that the replacement of offshore business with the speculative could prove a mistake (why 
change a winning horse?); that the new objectives were unduly anbitious; and that official reasons given for this change of direction did not sufficiently explain the sudden decision to embark on this radical U-turn in direction, barely five years following the setting up of MIBA, five years marked by satisfactory growth. It was generally acknowledged that the offshore industry was making a significant contribution to the local economy, and was relatively easy to explain, market and promote.

There can be no doubt that offshore companies generated a range of new business initiatives and opportunities, and new jobs were created. The incorporation of offshore companies generated income in a number of ways, including company registration, fees for licences and professional services, and income tax, as well as consequential tourism-related and other multiplier effect-related forms of income, such as air travel, local transport, printing, English language schools, rent of office space, purchase of property and telecommunication bills. ${ }^{17}$ Studies on the 1992 and 1993 performance of the offshore sector confirm its significant impact on the economy (see Table 6.1).

Table 6.1 Direct quantifiable income generated (1992 and 1993) from the Malta offshore sector (all figures in Lm 000 000s)

\begin{tabular}{lcc}
\hline & 1992 & 1993 \\
\hline MIBA and Registrar of Partnership fees & 736.3 & 953.8 \\
Taxation & 461.9 & 635.5 \\
Tourisn-related income & 257.7 & 329.6 \\
Salaries & 163.0 & 222.8 \\
Fees for services, rentals, & 1247.4 & 1720.5 \\
$\quad$ communication and other charges & 2866.3 & 3862.2 \\
\hline
\end{tabular}

* One Maltese lira (Lm) = approximately US\$2.6 in 1992 and 1993.

Source: The Economic Contribution of the Maltese Offshore Sector and its Potential, a document privately commissioned by the Association of Nominee Companies. Malta, EMCS Ltd, 1993.

Offshore business was deservedly swiftly gaining recognition as an important sector of the Maltese economy in its own right. MIBA's Annual Report for 1993 had highlighted this rate of growth:

It is worth noting that, at a comparable point in time, the registration of companies in competing jurisdictions had not reached a similar 
figure and this notwithstanding the fact that alternative jurisdictions were much less in number and regulation was much less rigorous than is the case presently in Malta. (MIBA, 1994, p. 6)

Double-taxation treaty partners and the EU were repeatedly, though not so much publicly, mentioned in this regard. Indeed, negative signals from some of Malta's double-tax treaty partners may partially explain the reason for Malta's radical change of direction: 'It is understood that negative reactions to the offshore benefits by some treaty partners were also a source of concern for the Maltese Government' (Gatt, 1997, p. 1).

Denmark had just unilaterally revoked its treaty with Malta, and another important double-taxation counter-party was, it was rumoured, exerting some pressure. ${ }^{18}$ It appears that Section 30(9) of the MIBA Act was raising some worried eyebrows; this stated that the provisions of the Act, including especially the extensive rules on confidentiality, were to override and enjoy priority over any double-taxation arrangements. For the government, and the Inland Revenue Department in particular, the offshore tag, so enthusiastically worn in 1988 , suddenly became uncomfortable.

Another factor which may explain this change of direction was a concern that the package of fiscal incentives and benefits being offered to non-resident investors may have been incompatible with the aims of harmonisation and the establishment of a European single market. The growing desire within the European Union to achieve exchange control and fiscal, including income tax, harmonisation could, on this basis, eventually slow down the processing of Malta's application, thwarting the government's wish to achieve quick entry into the EU as a full member. This concern with compatibility is indirectly disclosed in the 1993 MIBA Annual Report, which pointedly remarked:

The legislative and regulatory structure being set up has to conform with EU existing norms whilst remaining at least as competitive as the major European financial centres. (MIBA, 1994, p. 6)

\section{Relations with the European Union}

The European Commission's Avis (Opinion) issued in June 1993 on Malta's application to join the EU, submitted three years previously, did not carry any negative comments on the island's offshore business legislation (European Commission, 1993a). The Commission's Avis on the application submitted by Cyprus - a competing offshore location - was 
equally uncritical (European Commission, 1993b). Indeed, more than one example exists of the EU's readiness in certain circumstances not merely to tolerate but to actually assist offshore financial centres operating within its own territory. Luxembourg and Dublin are clear examples, while the EU has been underwriting Madeira's International Business Centre. Madeira is an island forming part of Portugal, an EU member state. Madeira is also a competing offshore jurisdiction, comparable in its approach and size to Malta. The June 1997 issue of The Economist carried a promotional feature on Madeira, wherein it is described as seeking to carve for itself:

a leading position among the international tax planning centres of the EU as a top-tier business location that offers competitive tax advantages in a soundly regulated and solidly reputable legal environment

The Atlantic island's International Business Centre is conceived as:

a special EU incentive to help the island bridge the development gap separating it from the rest of Western Europe. Membership of the EU provides both regulatory guarantees and full integration within a pre-eminent world market.

Did Malta miss the opportunity to become a second Madeira? The answer is elusive but much can be learnt from Malta's diplomatic relations with the EU. The Nationalist government's policy was clearly that of sending unambiguous signals to the rest of the world about Malta's foreign policy and its distinct European vocation. This deliberate attempt was probably deemed necessary to restore a modicum of respect and trust to Malta's international relations. After all, the previous Mintoff-led Labour government had arguably played a sinister game of 'maverick diplomacy' which kept Western Europe nervously guessing whether Libya, China, North Korea or the Soviet Union would gain a foothold on the island.

Proclaiming and demonstrating Malta's Europeanness may have been a necessary exercise, but in the process, the Malta government may have gone too far in accommodating Brussels' requests; this at a time when the attention of the EU for expansion liad shifted from South to East. On the (false) understanding that EU accession was within its sights, the Nationalist government may have opted to dismantle those very features of an offshore finance industry which would 
have ironically proved a critical negotiating lever in any eventual accession negotiations. This appears to be the most likely explanation behind Dr Camilleri's assertion quoted earlier of the offshore industry's alleged long-term unsustainability. Arguments in favour of preserving offshore banking in Malta in spite of non-compatibility with EU precepts were raised by senior government members: offshore finance centres could serve as safety valves plugging capital flight from Europe, which also explains why they continue to be condoned in the European heartland. ${ }^{19}$ However, these essentially economic arguments were ultimately overturned by the diplomatic ones. In retrospect, this decision appears to have been a net loss to Malta in its dependency management game.

\section{4: A Watershed}

Thus, 1994 represented a watershed for Malta's financial services legislation with brand new laws being enacted to regulate banking, investment services, collective investment schemes, insider dealing and the prevention of money-laundering. These were subsequently coupled to a new Companies Act and new proposed insurance legislation. It was a novel point of departure for the island's intentions to establish itself as a reputable and reliable location for international financial and business undertakings. ${ }^{20}$ Part 8 of the 1993 White Paper gives a brief description of the general purpose of the proposed amendments to the 1988 Act:

It is essential for the credibility of Malta as a financial services centre that there be coherence in the application of the rules in the different sectors of banking, insurance, collective investment, investment services, and so on. It is also highly desirable for Malta to offer foreign investors a 'one-stop-shop' in establishing and conducting operations in Malta.

For this reason, it is proposed to set up a single Financial Services Centre which would be responsible for supervision of collective investment schemes and persons providing investment services under the Investment Services Act, and would also have insurance and company law regulatory functions. It is proposed that MIBA evolve into the new Financial Services Centre as provided in the Financial Services Centre Bill. The Malta Financial Services Centre will continue to exercise the functions currently carried out by MIBA in relation to offshore companies. 
Certainly, one of the fundamental features of the new legislation was to eliminate the strict differentiation between offshore and onshore activities, and to introduce new legislative structures which no longer discriminate between the two and offer a novel tax-efficient environment which fits in favourably with the fiscal systems of other countries with whom Malta has double-taxation arrangements. The international consulting group KPMG was contracted by the Maltese government to prepare the necessary legislative instruments. New 'onshore' structures were implanted in the legislation to replace the offshore companies.

As a cumulative result of the various laws and ancillary measures adopted in 1994, the MIBA saw itself evolving from a strictly offshore business regulator into a composite regulator responsible for both offshore business and for certain onshore or domestic business. This latter included the regulation of domestic insurance and the administration of the activities covered by the new Investment Services Act. Plans to assign to the new Centre the added responsibilities for domestic banking have been suspended. The Central Bank of Malta has, on frequent occasions, voiced its opposition to the termination of its role as banking regulator, a role it has exercised since its constitution in the late $1960 s^{21}$

\section{DISCUSSION}

There are at least three conditions which appear to make Malta different from most of the other small island-based offshore finance centres. First, there is a small but significant well-structured and well-regulated domestic banking sector. Its tradition also ensures a crop of trained and experienced indigenous professionals. Other small jurisdictions may have no domestic industry at all. Second, Malta has a nominee company mechanism which is there to provide a local watchdog and accountability function. Third, offshore companies are subject to supervision by a regulatory authority and comparatively higher registration fees and running costs; onshore companies are exempt from these burdens. Usually, the situation is the other way round. Offshore companies in Malta benefit mainly from fiscal advantages, but their activities are overseen in a measure which would have been considered unacceptable for onshore companies. These exceptions do not however preclude a comparison of Malta's fortunes in offshore banking with other small, often insular, territories. For this reason, this last section offers a comparative analytical discussion on the nature of offshore and international financial 
services in small jurisdictions. Such a discussion will be obliged to consider two main issues. The first is methodological, and deals with the very real, extreme difficulties encountered while trying to write objectively and critically about such 'flagship' industries, all the more so when these are located in small territories and when criticism is forthcoming from locals. The second is political, and relates to the circumscribed options for finance-related economic activity by very small players on an increasingly standardising global stage.

\section{Through the Looking-Glass}

Although few of its own practitioners would be willing to admit it, much of the security and profitability of a finance or banking institution is preconditional on its image, the stature and robustness of the profile which it manages to develop and cultivate amongst a public, its potential customers. This fundamental fragility is the bête noire of an industry which, in almost subconscious reaction to its own vulnerability, invests so vigorously in promoting its own reliability and robustness - via extensive advertising, prestigious head office buildings, glossy brochures, cradle-to-grave services, and so on. The condition also makes it continually necessary for any bank, insurance business and the like to propagate faith and confidence in itself and its workings. Hence, anything but praise from within the institution will be subject to strict controls and filtering and liable to have a tightly restricted circulation, while proclamations from outside which are not totally positive and sympathetic will invariably be denigrated and rebutted. Too much hangs in the balance for a bank to adopt other than a viciously defensive attitude.

Such considerations apply to all banking and financial institutions. When directed towards international clients, the stakes are raised while the problem remains the same. Targeted now as potential clients are elite, cautious, discerning transactors in a position to choose - they must be more than fully convinced that a particular offshore location is discreet, safe and trustworthy. Because of the international dimension, the commercial activity also carries with it nationalistic overtones and the banking sector becomes a glorified (for so it must be) ambassador of a national economic regime, its stability and attraction as a site for financial investment. Any criticism, however justified, of an international finance institution, risks slandering the whole national economy within which it is based and operates.

These observations hold all the more when the national economic unit happens to be a small, often island, state. Typically, island micro-states 
suffer from the 'concentration phenomenon' (Selwyn, 1975): those which have entered the international finance industry do so with a small number of 'flagship' institutions on which the destiny of a whole industry often depends. Much hope, and therefore much responsibility, is placed on what are often no more than a handful of institutions and typically one small regulatory body. It is far more difficult to tolerate any damage to the profile of such discrete units. It has also been argued that small states have problems obtaining, training and keeping the specialist staff needed to operate such regulatory mechanisms in an effective manner (Shand, 1980, p. 16; Kersell, 1987, p. 106), judging also from the real risks of money-launderers worldwide looking for unsuspecting and relatively naïve financial centres to operate from:

The very isolation which attracts the romantics provides havens for the scoundrels who can dump their waste, launder their illegal money, explode their bombs, or excavate for phosphates or sand out of sight, and therefore out of mind, of the rest of the world. (Newitt, 1992, p. 3)

Irrespective of whether this is true or not, there is bound to be a stronger clampdown on critical information damaging the all-important aura of respectability of one's international financial centre. Like mirrors, these structures are meant to reflect economic strength, investor confidence and national pride. Like mirrors, they are to be exempted from the penetration of light; any criticism is expected to bounce harmlessly off and away from them on to other targets.

However, 'an offshore centre's reputation is seen as more dependent on the perceived stability of government policy than on its immunity to financial scandal - though a scandal can do damage' (Financial Times, 1998). Stability of economic and public policy is probably the supreme consideration of all potential foreign investors (Currie, 1985). Here again, very small economies, with their inevitable personalisation of administration (Baldacchino, 1997, p. 85; Kersell, 1992, p. 292), are liable to what amount to erratic policy shifts when their architects leave the stage. In spite of putting up a brave show of legal rationality, small jurisdictions remain vulnerable to ascription and particularism (after Benedict, 1967). Political rivalry and the absence of clear national interests may bring about dizzy shifts in policy between one particular government - or one particular minister - and another.

Any criticism, if at all, is least likely to be forthcoming from co-nationals. If there is a conspiracy of silence at work, ascertaining that nothing but politically correct information and statements about one's institutional 
showpieces make it into the public and media spheres, then those observers who are part and parcel of the socio-political fabric will think twice before uttering any vilifying statements (Boissevain, 1990, p. 17). Why? Because such an act will invariably prejudice their future status as citizens. They will be identified as those jeopardising the economic mainstay of the island economy. Being easily known and known about, they will also fall easy prey to a vicious exercise in social 'location' (Baldacchino, 1997, pp. 44-6), providing ex post explanations for the unfortunate expressions. Such will confirm the dictum that a prophet is never recognised in one's own country, and least so in a small place. These critics are likely to be snubbed and ostracised, socially if not physically, and will lose their social status and respect for having simply gone too far (Bray and Fergus, 1986, p. 97).

These observations are reinforced when one considers that critical capacity in a micro-state context is not only dampened as a result of social repression; the potential for such critique may not even be there in the first place. We are referring to small island locations which may not have a strong tradition in banking knowledge; which may have no tertiary education institutions; which may have no indigenous banking tradition from which an elite of indigenous experts may have been bred and nurtured over the years (Bray and Fergus, 1986, p. 95). Critical legislation may become law with hardly enough discussion and.with a lot of trust being placed on the recommendations of well-paid expatriate consultants. 'Treasure islands' are playing with fire.

A difficult dilemma thus presents itself. On one hand, being a local grants the benefits of access to insider information, a street-wise handling of cultural and political variables, a familiarity with people and events as they unfold, a privileged position to feel, discuss and read about relevant phenomena as they occur and in the vernacular language. All these and more the typical common expatriate observer cannot do. The latter must accept a condition of cultural alienation which, however, affords at least a comfortable degree of social distance. Keeping oneself at arm's length may not provide the best views and details of the case material, but it certainly provides a platform from which one can more comfortably expound one's views and criticism.

This is a painful, methodological quandary which must be skilfully negotiated by any small-state observer hoping to make objective, scientific declarations about the state of international financial institutions in his or her own small country where, within the 'strait-jacket of community surveillance' (Weale, 1992), people make it their business to know everyone else. 


\section{Mites at Large}

A second set of issues deals with the whole status of small island economies within a globalising project clearly under way. Very many trends are taking place today which are shepherding different actors into agreements that establish standards and/or consolidate mutually agreed or negotiated patterned ways of doing business; of doing democratic politics; of crafting industrial organisation; of developing communication systems. A number of related developments are to blame for this contemporary harmonisation movement: the differently levelling impacts of multinational corporations; communications technology; Western culture and its attractive democratic and consumer artefacts - these in contrast to the discrediting and bankruptcy of alternative solutions. In place is a universalising regime difficult to escape or thwart. Free trade replaces protectionism; pan-national agreements replace national autarchy; markets replace plans; 'best practices' replace good practices; common sense replaces good sense; and a worldwide web of conforming practices draws near (Baldacchino and Greenwood, 1998).

Does this scenario presage the coming into force of the convergence thesis, when all mankind will be inexorably drawn into the vortex of 'one-worldism': one culture; one ideology; one system of government; one trade regime which operates strictly on the principles of scarcity and competition (Levitt, 1983, pp. 92-6)? Not so. It is clear that globalisation creates difference and identity at one level even as it bulldozes across these at another. New expressions of locality have indeed been strengthened in the context of the new spaces for action created in a global village network; while other sites of locality may be clean forgotten and brushed aside by the advancing dynamic. Small jurisdictions must not lose heart at the global project taking place around them - it does not necessarily spell their doom and decline and may indeed provide them with new, niche opportunities.

Why should small jurisdictions feel at all threatened by globalisation? It must be admitted that small territories have not shirked from deploying their small size as a positional advantage on the world stage. Being small, they do not exert any significant effect on the global system. Therefore, they have often behaved in a manner which has been in contravention of existing general principles: expecting privileged relations with would-be sponsors; distorting the pricing strategies of critical cash crops; securing the free access of own products to desirable foreign markets (Baldacchino, 1993, p. 38). For all their self-declared 
prestige, international financial centres - like flags of convenience typically attract clients precisely because they offer better deals than those in place in the clients' home financial institutions.

The 'post-Cold War' world may be heading for a level playing field: initiatives are in place intended to implement measures to combat harmful tax competition. ${ }^{22}$ Yet, meanwhile, the small state feels it has a right to move the goal posts. Being small, it takes the calculated risk that its activities, while implicitly recognised as foul and unfair by the other players, will nevertheless be condoned and tolerated. Indeed, vulnerable small states could also provide some opportunity for big players to exhibit solidarist 'aid packages', 'bilateral agreements' and 'special deals'. Observers are likely to turn a blind eye to 'below the belt' antics and 'free riding', because they are the antics of Lilliputian players (Keen, 1996). These can do but little harm. ${ }^{23}$ Indeed, if these small players prove too successful in their anomalous behaviour, they will attract international attention and instigate concerted drives to check their course and damage.

Witness a case in point. Smallness of size and of political clout must have been important factors in the unilateral abrogation by the USA of its double-taxation treaty with Malta, which expired in December 1997. The remarkable suggestion has been put forward that the USA may have seen the treaty with the small island as 'disposable', while useful enough to terminate in order to make an example and put pressure on the Swiss government:

The Swiss were reluctant to accept U.S. anti-avoidance proposals of the treaty between the U.S.A. and Switzerland which was under re-negotiation at the time. The heavy-handed technique appears to have worked: the Swiss agreed to U.S. demands and the Maltese lost their treaty. (Doggart, 1997, p. 30)

This is why international financial centres which offer 'better' deals, like the infamous flags of convenience, are not likely to survive in the medium term - precisely because they have drawn off such considerable tonnage (of capital, of shipping) away from their intended beneficiaries (see, for example, Carse, 1998, p. 191). Like the pirates which have accompanied most of history, they risk the wrath and anger of the powerful only if they significantly dent their coffers.

Indeed, piracy was a particularly profitable and vital economic activity and earner of foreign currency for Malta and other island territories, especially in the sixteenth and seventeenth centuries. Corsairs duly 
licensed by, and flying the flag of, the Order of St John based in Malta brought the Order into frequent conflict with other states - such as the powerful Republic of Venice - interested in cultivating friendly and commercial relations with the Ottoman Empire (Mallia-Milanes, 1992, p. 125).

Like modern-day corsair lairs, small states have found no difficulty in justifying such 'perverse' behaviour (Hampton, 1996, p. 3). Their destiny is, first, one of dependency. They are 'wide open' socio-economies with no appreciable internal market to speak of; they are open to all forms of import flows from abroad; their very economic existence has often depended on sustained fiscal transfers from core to periphery. From a strictly structural, closed economy perspective, many small jurisdictions are simply non-viable. To make matters worse, long and deep colonial penetration has established a standard of living more akin to extant Western levels and one which is simply impossible to maintain on the basis of natural resource endowment and productive capacity. They have thus placed themselves strategically as internationally attractive platforms, disguised magnets for the drawing of aid, rents, grants, tourist flows and other largesse, siphoned from rentsurplus economies, households or firms. Even the most unlikely of 'products' - including postage stamps, passports, kitsch souvenirs and electronic mail addresses - are commandeered and brought to bear. International finance, and its diverse economic spin-offs, is a lucrative form of transfer one would rather not go without.

Yet, small states, like other states, are not mere passive participants on the world stage. The metaphors of imperial flotsam and jetsam, of manufactures of empire (Naipaul, 1972) or of small oarless boats at the mercy of the waves (Baldacchino, 1994) are evocative and powerful: 'Protectionism is never so cruel as when it ends' (The Economist, 1997). But these same metaphors are also partial. Small states are actors and interactors, apart from reactors. All the more so if they are states and therefore they are beneficiaries of a political status which other sovereign territories will feel some obligation to defend in dire straits. Hence, their second destiny is that of dependency management. If they cannot help being vulnerable, they can nevertheless exercise diplomacy, strategy and an imaginative variety of other tactics to break down the opposition and guarantee the quality of life that their citizens aspire to. The Cold War setting provided ample scope for playing off one superpower with another. The game today is, must be, played differently: threats of terrorism, drug-trafficking, money-laundering, shipment of arms, waves of immigrants, natural environmental crises, the deterioration of world 
heritage sites or the simple political instability which would result from downturns in the quality of small island life - these are amongst the main 'excuses' used to generate and manipulate international tolerance for small state difference, to justify transfers and artificial pricing, to ensure survivability.

This chapter has discussed the development of the Malta Financial Services Centre and of the legal and political framework within which it has been established and operated. Concurrently, a sober assessment has been made of the anomalous status of international financial centres in the modern world, particularly as administered from small island bases. Acknowledgement is also made to the powerful and conservative social filters which work against all but the essentially dogmatist and selfrighteous accounts of international finance industries as propounded by their administrators, as well as by other national spokespersons. Locals would be shrewd not to beg to differ.

\section{Notes}

1. The Maltese Islands are situated 93 kilometres south of Sicily and 290 kilometres north of Libya. The 1995 Census reports a resident population of 379000 living on a land area of 316 square kilometres. A British.colony since 1800 , Malta became politically independent in 1964 and a republic in 1974. GDP per capita is US $\$ 9090$ (1996 estimates).

2. The Committee was headed by Dr Mario Felice LLD, former shadow minister of finance and first chairman of the Malta International Business Authority and later on of the MFSC until 1995. The report, which remains strictly confidential, was presented to the prime minister in December 1997.

3. The Insurance Business Act of 1981 is due to be replaced by a new Act in 1998. At the time of writing, new legislation is being debated by Parliament. As from 1 January 1996, the Commercial Partnerships Ordinance has been replaced by a new Companies Act, largely modelled on recent English companies legislation. The Banking Act of 1970 has been largely superseded by a new law passed in 1994. The Merchant Shipping Act is still substantially in force in its original shape; Malta is currently the world's sixth top ship-registration jurisdiction on the basis of tonnage (Malta Maritime Authority Annual Report, 1996-7).

4. International Business Activities - Legislative Proposals, September 1988, Malta, Department of Information.

5. Ibid.

6. These included Chase Manhattan Bank SA.

7. Parliamentary Debates, The Times, Malta, Progress Press, 25 October 1988. 
8. The Honourable Lino Spiteri, Shadow Minister of Finance, during an amendment discussion, Sitting 418, 27 July 1990.

9. The Honourable Alfred Sant (now Prime Minister of Malta), Parliamentary Sitting 418, 27 July 1990.

10. Ironically, this was against the advice of the International Monetary Fund, as submitted in a 1977 report, commissioned by the Maltese government. See IMF (1977).

11. A nominee company is only permitted to hold as a beneficial owner in its own right one share or a number of shares whose total value did not exceed one Maltese lira (US\$3 approximately).

12. International Business Activities - Legislative Proposals, September 1988, Malta, Department of Information.

13. They may do this in one of three ways: by converting into an ordinary (onshore) company becoming subject to the ordinary rules of the land; by redomicilation to another jurisdiction; or via dissolution and winding up.

14. Malta Financial Services Centre - Legislative Proposals, November 1993, Department of Information.

15. Dr Andre Camilleri, address to the State of the European Union Conference, 1995, University of Malta, European Documentation and Research Centre.

16. The Malta Independent, Malta, Standard Publications, 2 October 1994, p. 35.

17. The Economic Contribution of the Maltese Offshore Sector and its Potential, a document privately commissioned by the Association of Nominee Companies. Malta, EMCS Ltd, 1993.

18. 'This reaction ... should come as no surprise. The effectiveness of an offshore financial centre as a refuge from onshore tax persecution is bound to be thwarted by a number of counter measures intended to plug tax leakage. The Maltese offshore initiative has been a success and we now have to start contending with the problems of our success.' "And now: the Malta Financial Services Centre', Dr A. Galea Salomone, The Sunday Times (Malta), 5 September 1994.

19. Minister Joe Fenech, Sitting 419, had already argued that OFCs were not incompatible with eventual EU membership.

20. For sone evidence of this success, see Caroline Doggart's (1997) assertion that Malta 'has high standards of legal, social and financial services'.

21. In the United Kingdom, banking supervision has been transferred to all enlarged, independent, statutory authority - the Financial Services Authority - whose range of competences mirror those of the MFSC.

22. 'Towards a Taxation Strategy for the European Union', Agence Europe Bulletin, No. 2051, 24 September 1997, and 'EU Tries to Rein In the Special Havens', Financial Times (UK), 22 January 1998, p. 8.

23. MITE is also an acronym for monopoly, intimacy in the context of totality from which emigration is the only escape route. See the small-scale syndrome described in Baldacchino (1997). 


\section{References}

Baldacchino, G. (1993) 'Bursting the Bubble: The Pseudo-Development Strategies of Microstates', Development and Change, vol. 24, no. 1, pp. 29-51.

Baldacchino, G. (1994) 'Labour Policy in Microstates: Or, the Management of, and by, the Crew of a Drifting Vessel', Bulletin of Eastem Caribbean Affairs, vol. 19 , no. 1, pp. 44-52.

Baldacchino, G. (1997) Global Tounism and Informal Labour Relations: The Small Scale Syndrome at Work. Mansell, London.

Baldacchino, G. and Greenwood, R. (1998) 'Editorial Introduction', in Baldacchino, G. and Greenwood, R. (eds), Competing Strategies of Socio-Economic Development for Small Islands. Institute of Island Studies, University of Prince Edward Island, Canada.

Benedict, B. (1967) 'Sociological Aspects of Smallness', in Benedict, B. (ed.), Problems of Smaller Territories. Athlone Press, London.

Boissevain, J. (1990) 'Why Do the Maltese Ask So Few Questions?', Edlucation, Journal of the Faculty of Education, University of Malta, vol. 3, pp. 16-23.

Bray, M. and Fergus, H.E. (1986) 'The Implications of Size for Educational Development in Small Countries: Montserrat, a Caribbean Case Study', Compare, vol. 16, no. 1, pp. 91-102.

Briguglio, L. (1988) The Maltese Economy: A Macro-Economic Analysis. David Moore Publications, Malta.

Brock, C. and Smawfield, D. (1988) 'Education and Development: The Issue of Small States', Educational Review, vol. 40, no. 2, pp. 227-39.

Carse, S. (1998) 'Majoring in Finance: Implications and Key Issues', in Bowe, M., Briguglio, L. and Dean, J.W. (eds), Banking and Finance in Islands and Small States. Pinter, London..

Currie, J. (1985) Export Processing Zones in the 1980s, Special Report No. 190. Economist Intelligence Unit, London.

Doggart, C. (1997) 'Tax Havens and Their Uses', in The Economist Intelligence Unit Research Report. The Economist Intelligence Unit, London.

The Economist (1997) 'Expelled from Eden', 20 December, pp. 41-4.

European Commission (1993a) The Challenge of Enlargement: Commission's Opinion on Malta's Application for Membership. European Commission, Luxembourg.

European Commission (1993b) The Challenge of Enlargement: Comnission's Opinion on Cyprus' Application for Membership. European Commission, Luxembourg.

Financial Times (1998) ‘Banking Saandals Tarnish Golden Reputation’, 22 January, p. 8 .

Gatt, N. (1997) 'Salient Aspects of the Definition of International Trading Company in the Income Tax Act', Malta Institute of Taxation Newsletter, October.

Hampton, M.P. (1996) The Offshore Interface: Tax Havens in the Global Economy. Macmillan, Basingstoke.

International Monetary Fund (1977) Malta as a Financial Centre, unpublished report, IMF Central Banking Service, Washington DC, June.

Kakazu, K. (1994) Sustainable Development of Small Island Economies. Westview Press, New York. 
Keen, M. (1996) 'Taxation in Small States', paper presented at International Conference on the Effects of Economic Globalisation and Regional Integration on Small Countries, Nicosia, Cyprus, September.

Kersell, J.E. (1987) 'Government Administration in a Very Small Microstate: Developing the Turks and Caicos Islands', Public Administration and Development, vol. 8, no. 1, pp. 95-107.

Kersell, J.E. (1992) 'An Overview of the Concept of Smallness', in Baker, R. (ed.), Public Administration in Small and Island Slales. Kumarian Press, West Hartford, Conn.

Levitt, 'T. (1983) 'The Globalization of Markets', Man'and Business Review, no. 83 , pp. $92-102$.

Mallia-Milanes, V. (1992) Venice and Hospitaller Malta: 1530-1798. I'EG Publications, Malta.

Metwally, M.M. (1977) Growth and Performance of the Maltese Economy. A.C. Aquilina \& Co. Malta.

MIBA (Malta International Business Authority) (1994) Anmual Report for 1993. MIBA, Malta.

Munck, R. (1988) The New Intemational Labour Studies: An Introduction. Zed, London.

Naipaul, V.S. (1972) The Overcrowded Banacoon and Other Articles. André Deutsch, London.

Newitt, M.D.D. (1992) 'Introduction', in'Hintjens, H.M. and Newitt, M.D.D. (eds), The Political Economy of Small Tropical Islands: The Importance of Being Small. University of Exeter Press, Exeter.

Selwyn, P. (1975) 'Industrial Development in Peripheral Small Countries', in Selwyn, P. (ed.), Development Policy in Small Countries. Croom Helm, Beckenham.

Shand, R.T. (1980) 'Island Smallness: Some Definitions and Implications', in Shand, R.T. (ed.), The Island States of the Pacific and Indian Oceans: Anatomy of Development, Monograph No. 23. Development Studies Centre, AusIralian National University, Canberra.

Weale, D. (1992) 'Everybody's Business', in Them Times. Institule of Island Studies, University of Prince Edward Island, Canada.

Whitmore, E. (1988) 'Insurance in Malta', in Azzopardi, E. and Ileywood, P. (eds), Issues: Aspects of An Island Economy. The New Economics Society, Malta. 